\title{
Undergraduate Students' Ability in Constructing Cohesion in the Background of the Problem of Thesis
}

\author{
Yeli Eka Sintya ${ }^{*}$ and Muhammad Al Hafizh² \\ ${ }^{12}$ English Department, FBS Universitas Negeri Padang, Padang, Sumatra Barat 25131, Indonesia, Email: \\ *Corresponding author.Email: yelieka94@gmail.com; m_alhafizh@yahoo.com
}

\begin{abstract}
The background of the problem is an important component of the thesis. Background of the problem is the first chapter of the thesis that contains the answers to what and why the research needs to be done. Making a background of the problem is not easy, college students are required to arrange ideas systematically so that people are interested and believe in reading the background of the problem of a thesis, then there must be cohesion. The students of a college are expected to write a thesis coherently with the right use of cohesive devices. This article has aim to analyze the ability of undergraduate students in constructing cohesion in the background of the problem of thesis at UIN Imam Bonjol Padang. The descriptive research design was used in this study to describe their ability in constructing cohesive devices. To find out their ability, 20 background of the problems from different thesis were chosen by using random sampling. It was found that some of undergraduate students had lack ability in constructing cohesion in their background of the students of thesis at UIN Imam Bonjol Padang. Thus, it can be interpreted if undergraduate students had a lack of understanding and could not apply the cohesion well enough in writing the background of the problem of thesis.
\end{abstract}

\section{Keywords: Cohesive devices, background of the problem, thesis}

\section{INTRODUCTION}

At the tertiary level, academic writing is used to examine students' understanding of writing skills. At the end of their studies, tertiary students must exhibit their writing ability in the form of a research report or thesis. Meanwhile, Brown [1] says that ESL/ EFL students will have a harder time writing a thesis.

To teach English in Indonesia, college students must complete an english education program in a university of education. A thesis is one of the graduation requirements. A thesis is a piece of academic writing that each student is required to finish. The ability to produce a quality sentence in a thesis is the most significant need.

An introduction is one of the most crucial elements of a thesis. The introduction is the first chapter of the thesis, and it answers the questions of what the research is for and why it is needed. According to Bathia quoted in Flowerdew [2] the introduction plays a critical function in demonstrating the research's relationship. Background of the problem, identification of the problem, limitation of the problem, formulation of research problem, purpose of the research and defenition of key term are the six sub-chapters that make up the introduction of the thesis. In a research paper, the background of the problem is quite crucial. It is because it acts as the basis of the research article, exposing the researcher's purpose for performing the study, the theories that support his or her conclusions, and the fundamental information important to the study's applicability to larger domains, as well as showing concisely the extension of the research topic [3].

Because introduction is such a crucial element of the thesis, students should be able to indroduction wellwritten introduction, particularly as it relates to the background of the problem. A well-written background of the problem, on the other hand, is difficult to write for three reasons. The first, background of the problem, is usually produced in the first chapter of the thesis writing process. In response to this statement, the supervisor may pay more attention to the introductions written by the students. As the background of the problem is a synopsis of the entire thesis, the second should encompass all components of the thesis and be presented in limited terms. The final section, a background of the problem, is a condensed version of the entire thesis. In the meantime, students must write every aspect that should be written in the background of the problem. They only have a small amount of room for it, though. Choosing the right sentences to use in the background of the problem will be challenging in this regard. 
The purpose of the background of the problem is to emphasize the reader the importance of the research, a background of the problem must be accompanied by arguments, an argument must be cohesive and to build a good argument must be a well-written theme and rheme. Actually making a background of the problem is not easy, college students are required to arrange ideas systematically so that people are interested and believe in reading background of the problem of a thesis, then there must be cohesion.

Based on the explanation above, students should be able to overcome several difficulties in writing background of the problem of a thesis. The difficulties are not only deal with structure, words selection, or text organization but also in terms of creating a coherent, cohesive, rheme and theme in writing. The skill to create a cohesive text is essential. However, even when writing in one's native tongue, even language specialists concede that it is difficult to write properly.

College students are expected to prepare a research paper that is well-organized and uses cohesive devices. The term "cohesive device" refers to a device that represents a cohesive relationship. Cohesive devices, According to Halliday and Hasan [4], there are two forms of cohesion: grammatical cohesion and lexical cohesion.

Grammatical cohesion is demonstrated through reference, ellipsis, substitution, and conjunction.

Then, reiteration and collocation are employed to achieve lexical coherence. All of these devices are used to connect sentences in a conversation into meaningful ones.

As a consequence, the background of the problem must be stated as a continuous text rather than a collection of disconnected sentences. For students at the tertiary level, creating a grammatical and lexical unified academic writing is also difficult. According to Emilia [5], A text is cohesive if the sentences are semantically linked and consistent throughout. In other words, students must write a cohesive introduction in order for readers to comprehend the background of the problem.

According to Halliday and Hasan [4], the grammatical and lexical connection inside a text or phrase. Cohesion is a concept that refers to a connection that connects and adds meaning to a text. Furthermore, Derewianka [6] asserts that there are several strategies that may be used to structure a text cohesively at the text level. These cohesive techniques link disparate components in the text, helping the reader to understand the text's meaning.

In connected discourse, the connection between sentences may play a function. Cohesion is required by the writers to connect the sentences. "The relation of meaning in a text is what cohesion is all about. Because a text is a unit of meaning rather than a form, it characterizes something as a text. It is the source of the text, which has a variety of meanings in relation to what is being said and written, as well as its semantic context." Jabeen, et alcited in Kuncahya [7]. Cohesiveness is defined as a set of ties in which each paragraph relates to a single instance of cohesion, which is communicated partly via grammar and partly through language. It is for this reason that grammatical and lexical cohesiveness exist. According to Emilia et al [8] "cohesion does not depend on the structural unit in the text, such as phrase or sentence." Cohesion is found beyond the phrase or clause, which is meaning."

According to Halliday and Hasan [4], "cohesion is a collection of linguistics methods that connect concepts without making the semantic linkages underlying them obvious". It denotes the device for directly connecting the concepts in the text via coherent sections.

Furthermore, "cohesion refers to the range of grammatical and lexical possibilities available for linking an aspect of language with what came before or what follows in a text".This is achieved through meaningful linkages that occur both within and across sentences" Halliday \& Hasan [4]. As a result, cohesion uses cohesive linkages to arrange and connect phrases, resulting in a text that is cohesive rather than a collection of disconnected sentences.

In their book Cohesion in English, Halliday and Hasan [4] split cohesion into grammatical and lexical cohesion. Grammatical cohesion is demonstrated through reference, substitution, ellipsis, and conjunction. Meanwhile, reiteration and collocation are examples of lexical cohesiveness. This is because they are both determined by two separate causes. Grammar and words are the two terms. The difference is unmistakable at the lexico-grammatical level

\section{METHOD}

The descriptive qualitative research method was employed in this study. According to Silverman [9], descriptive research is used to describe and interpret. The reason for this is that the researcher descriptively evaluated the data in the background of the problem of thesis. The research used a random sampling technique in choosing a sample, they are 20 background of the problem of English Education undergraduate students' thesis in 2020 academic year at UIN Imam Bonjol Padang that used in this research. And source of data The researcher were taken 9 paragraphs of background of the problem from each student.

In the process of collecting data, The researcher collected data using the background of the problem as an instrument, and the data was utilized to analyze students ability in build cohesive devices in the background of the problem of the thesis of English students at UIN Imam Bonjol Padang. To see the ability to write cohesive devices, there are five types of cohesive device that were analyzed in the background of the students of thesis writing, namely: references, ellipsis, conjunctions, substitutions, and lexical cohesion. In looking at the level of students' ability in cohesive writing, the researcher refers to the ideal indicators of cohesive devices adapted from the understanding of several experts.

Furthermore, the grading rubric derived from Hamplyon [10] Each indicator contains several 
categories or ratings. The optimum cohesiveness has a score of 6 and is classified as high/very excellent. The scale runs from 1 to 6 , with the following categories and scores: 1 for low/very weak, 2 for weak, 3 for low average, 4 for high average, 5 for good, and the last 6 for high/very good.

This study examines five cohesive devices, each of which is labeled with a special code. The code for each cohesive device identified during this study is displayed in the table below, Dania [11].

Table 1. The Code of Cohesive Devices for Data Analysis.

\begin{tabular}{|l|l|l|}
\hline NO & COHESIVE DEVICES & CODE \\
\hline 1. & Reference & $\mathrm{R}$ \\
\hline 2. & Substitution & $\mathrm{S}$ \\
\hline 3. & Conjunction & $\mathrm{C}$ \\
\hline 4. & Elipsis & $\mathrm{E}$ \\
\hline 5. & Lexical Cohesion & $\mathrm{LC}$ \\
\hline
\end{tabular}

According to the figure above, reference is represented by the letter $\mathrm{R}$. The code $\mathrm{S}$ is then assigned to any substitutions discovered throughout the study, Conjunction is subsequently assigned the code $\mathrm{C}$, Ellipsis is marked by the symbol E, and lexical cohesion is denoted by the code LC. Furthermore, the data will be analyzed using the following process:

1. Giving the code into the words that symbolize each cohesive devices are given in the figure 1 .

2. Recapitulating the data outcomes of each text. The total number of references, substitutions, conjunctions, ellipses, and lexical cohesions discovered in the text will be recapitulated.

3. Assessing a student's ability to construct cohesive devices. Using the Holistic Scoring Hamp-Lyon (1992), the ideal cohesive devices are identified with the score from $1-6$.

\section{FINDING AND DISCUSSION}

The researcher averaged all of the students' findings to assess the students' ability to incorporate cohesive devices into their writing. The mean evaluations were then converted to HampLyon's holistic grading criterion [10]. The optimal cohesiveness device has defined a score of 6 with a high/very excellent category with several categories or scores in each indicator. The scale runs from 1 to 6 , with the following categories and scores: low/very weak 0 percent (1), weak 20 percent (2), low average 21-40 percent (3), high average 41-60 percent (4), good 61-80 percent (5), and high/very good 81-100 percent (6).

Table 2. The Average score of Cohesion Devices.

\begin{tabular}{|l|l|l|}
\hline Type of cohesive devices & Frequency & Percentage \\
\hline Reference & 165 & $35,25 \%$ \\
\hline Subsitution & 8 & $1,70 \%$ \\
\hline
\end{tabular}

\begin{tabular}{|l|l|l|}
\hline Eipsis & 12 & $2,56 \%$ \\
\hline Conjunction & 243 & $51,92 \%$ \\
\hline Lexical cohesion & 40 & $8,54 \%$ \\
\hline
\end{tabular}

Figure 2 depicted the average of students' ability in incorporating cohesiveness into their background of the problemof thesis writing. Figure 2 displayed the average percentage of each cohesive device as well as the overall average score for building cohesiveness in the background of the problem of thesis.

According to Figure 2, the average score in presenting reference was 35.25 percent. This suggested that their capacity to express references was in the Low Average (LA) range. In using references, students are quite able but still a little less precise. The second cohesive device was subsitution, with an average score in expressing subsitution of 1.70 percent, placing it in the Weak (W) category. Following that, the students' ability in portray elipsis in the backdrop of a thesis problem with an average percentage of 2,56 percent was also rated as Weak (W). In using the ellipsis, students are still very weak, they only use the substitution very little and the ellipsis, they still use a lot of repetition of words in each paragraph. Next, the fourth cohesive devices improved. It was discovered that the students' ability to represent conjunction with an average score of 51,92 percent, the use of conjunctions is quite good, some students are able to use conjunctions correctly or more accurately, and their capacity to depict conjunction was in the High Average (HA) classification. The last cohesion device was lexical cohesion, where students' ability to express lexical cohesion was Weak (W) with an average score of 8,54 percent, indicating that students' ability to employ lexical cohesion is still extremely low.

More than half of the students demonstrated a low level of average ability in creating cohesive devices in the background of the problem of thesis. All of the percentages indicated the students overall ability to establish cohesion. Finally, all of the figures demonstrated the students' abilities to construct cohesive devices. The statistics then detailed the students' scores in each cohesive device indication, which related to their ability to incorporate cohesive devices into their writing. According to the findings of the research, students' overall ability to create cohesiveness in the background of the problem of thesis written by UIN Imam Bonjol Padang students was in the low average range.

\section{CONCLUSION}

According to the findings, the students capacity in constructing cohesive devices in the context of the background of the problem of thesis writing by undergraduate students at UIN Imam Bonjol Padang is low on average, with some students scoring in the range of $1-51$ percent, indicating that they have a low level of understanding on cohesive devices.

The sequence of the types of cohesive devices from the highest to the lowest made by the students was 
conjunction, reference, lexical cohesion, elipsis and subsitution.

Based on the results, the researcher would like to make the following recommendations: (1) undergraduate students of the English education department at UIN Imam Bonjol Padang are advised to be aware of the types of cohesive devices in writing, particularly when writing their background of the problem of a thesis. (2) Undergraduate English education department lecturers at UIN Imam Bonjol Padang are encouraged to provide more writing practices related to students' ability to build cohesion into their writing, whether writing at home or on campus, and to be aware of incredibly quick writing, which copies sources directly from the internet.

\section{AUTHORS' CONTRIBUTIONS}

This paper offers the findings of a study on the capacity to build cohesiveness in the context of a thesis written by the undergraduate students english education department of UIN Imam Bonjol Padang. In reaching the goal of this study the researcher analyzed the students' ability based on the cohesive devices introduces by Halliday and Hasan. However, it was assessed using the scoring rubric that is stated by Hamp-Lyon.

\section{ACKNOWLEDGMENT}

The researcher would like to thanks to Allah S.W.T who has given the grace and gifts to write this paper. Then, thanks to the advisor Dr. Muhammad Al Hafiz, S.S., M.A. finally, the researcher would like to express the deepest appreciation goes to parents and friends who have given support, prayer and motivation.

\section{REFERENCES}

[1] Brown, H. Douglas. (2007). Language Assesment: Principles and Classroom Practices. New York: Pearson Education, Inc.

[2] Flowerdew, John. (2002). Academic Discourse. London: Pearson Education Limited.

[3] McMillan, James H. (2008). Educational Research: Fundamental for Consumer, Fifth Edition.Boston: Pearson International Edition.

[4] Halliday, M. A. K. \& Hasan, R. (1976). Cohesion in English. London: Longman.

[5] Emilia, E. (2014). Introducing Functional Grammar. Bandung: Pustaka Jaya.

[6] Derewianka, B. (2011). A New Grammar Companion for Teachers. Riverwood: Primary English Teaching Association.

[7] Kuncahya, O. A. (2015). Cohesion in Narrative Text Presented in the Electronic Textbook of Senior High School Grade X Entitled "Developing English Competence".

[8] Emilia, E. Habibi, N \& Bangga, L.A. (2018). An analysis of cohesion of exposition texts: an indonesian context. Indonesian Journal of Applied Linguistics : Vol. 7 No. 3, pp. 515-523
[9] Silverman, D. (2005). Doing qualitative research: A practical handbook (2nd Edition). London: SAGE Publications Ltd

[10] Hamp, Lyon. L. (1992). Holistic Writing Assesment for LEP Students. In Office of Billingual Education and Minority Languages Affairs (ed). Procedings of Second National Research Symposium on Limited English Proficient Student Issues. Focus on Evaluation and Measure. Volume 2. Washington Dc: Obemla. 317-358.

[11] Dania, R. (2016). An Analysis of Cohesion in The Abstract of The Theses Written By Undergraduate Students of English Education Program at One State University In Bandung. Universitas Pendidikan Indonesia : Repository.upi.edu. Perpustakaan.upi.edu. 